\title{
PERBANDINGAN EFEKTIFITAS METODE DEMONTRASI DAN VIDEO SADARI DALAM PENINGKATAN MOTIVASI DETEKSI DINI KANKER PAYUDARA
}

\section{COMPARISON OF THE EFFECTIVENESS OF METHOD OF DEMONTRATION AND VIDEO BEING IN IMPROVING MOTIVATION OF BREAST CANCER EARLY OF DETECTION}

\author{
Suparmi $^{1}$, Winarni ${ }^{2}$ \\ Stikes 'Aisyiyah Surakarta Prodi DIII Kebidanan \\ email:mamikkajad@yahoo.co.id
}

\begin{abstract}
Abstrak
Kanker payudara adalah keganasan yang paling sering pada wanita di negara maju dan nomor satu di negara berkembang dan merupakan 29\% dari seluruh kanker yang didiagnosis tiap tahun. Di Jawa Tengah Kanker payudara menduduki peringkat pertama dibandingkan dengan jumlah kasus kanker yang lain yaitu sebanyak 9.542 kasus (48,59\%). Tujuan penelitian ini untuk mengetahui perbandingan efektifitas metode demontrasi dan video SADARI terhadap peningkatan motivasi praktek SADARI sebagai upaya deteksi dini kanker payudara. Metode. Penelitian ini menggunakan quasi eksperiment dengan pre test-post test design. Pengambilan sampel menggunakan probability sampling dengan teknik cluster random dan proportional random sampling. Jumlah Sampel 86 responden. 43 responden diberikan perlakuan metode demontrasi dan 43 responden diberikan perlakuan pemutaran Video SADARI. Pengumpulan data dengan kuesioner. Uji Statistik dengan t-test dan uji Independent t test. Hasil: Ada perbedaan signifikan skor motivasi antara kelompok demontrasi dan kelompok VCD setelah dilakukan eksperimen $\left(t_{\text {hitung }}(3,400)>t_{\text {tabel }}(1,67)\right.$. Kesimpulan: metode demontrasi lebih efektif digunakan dalam meningkatkan motivasi praktek SADARI dibandingkan dengan metode pemutaran video SADARI.
\end{abstract}

Kata Kunci: Demontrasi, video, motivasi praktik SADARI.

\begin{abstract}
Breast cancer is the most frequent malignancy in women in developed countries and number one in developing countries and constitutes 29\% of all cancers diagnosed each year. In Central Java Breast cancer was ranked first compared with the number of other cancer cases as many as 9,542 cases (48.59\%). Purpose; The Purpose of this research to know the effectiveness of Demonstration method and the video SADARI to improve the motivation of SADARI practice as an effort to detect early breast cancer. Method This research uses quasi experiment with pre test-post test design. Sampling using probability sampling with random cluster technique and proportional random sampling. Total sample 86 respondents. 43 respondents were given treatment of demontration method and 43 respondents were given treatment of SADARI Video playback. Data collection with questionnaires. Statistical Test with T-test. Results: There were significant differences in motivation scores between the demonstration group and the VCD group after the experiment $((3,400)>(1,67)$. Conclusions: Demonstration methods were more effectively used in improving the SADARI practice motivation than the SADARI video-play method.
\end{abstract}

Keywords: Demonstration, video, motivation of SADARI practice. 


\section{PENDAHULUAN}

Kanker payudara adalah keganasan yang paling sering pada wanita di negara maju dan nomor satu di negara berkembang dan merupakan 29\% dari seluruh kanker yang didiagnosis tiap tahun. Berdasarkan Phatological Based Registration di Indonesia, kanker payudara menempati urutan pertama dengan frekuensi relatif sebesar $18,6 \%$. Kasus penyakit kanker yang ditemukan di Provinsi Jawa Tengah pada tahun 2015 sebanyak 18.954 kasus meningkat bila dibandingkan dengan tahun 2010 sebanyak 13.277 kasus, terdiri dari Kanker servik 6.899 kasus $(35,13 \%)$, Kanker payudara 9.542 kasus (48,59\%). (Profil dinkes Jawa Tengah, 2015). Di Kabupaten Sukoharjo pada pada tahun 2014 angka kejadian Kanker Payudara sebanyak 249 kasus, Kanker cerviks 80 kasus, kanker hepar 34 kasus. Kasus kanker payudara menduduki peringkat pertama di Kab Sukoharjo (Profil Dinkes Sukoharjo, 2014).

Tingginya angka kejadian Kanker Payudara di kabupaten Sukoharjo mendapat perhatian dari semua pihak baik oleh pemerintah atau peran serta dari masyarakat. Bentuk peran serta masyarakat mulai dari promotif, preventif, kuratif, rehabilitatif. Pencegahan primer untuk mendeteksi kasus Kanker payudara, bisa dilakukan dengan cara yang paling mudah yaitu dengan pemeriksaan Payudara Sendiri (SADARI).

Tujuan penelitian ini adalah mengetahui perbandingan efektifitas metode demontrasi dan video SADARI terhadap peningkatan motivasi praktek SADARI sebagai upaya deteksi dini kanker payudara.

\section{METODE PENELITIAN}

Rancangan penelitian ini menggunakan quasi eksperiment, desain yang dipakai adalah pre test-post test design. Pada kelompok yang diberi perlakuan menggunakan media video compact disc dan demontrasi dalam meningkatkan motivasi praktek SADARI sebagai upaya deteksi dini kanker payudara. Populasi ini adalah ibu-ibu PKK di wilayah desa Grogol, Sukoharjo sebanyak 423 orang. Jumlah sampel 20\% dari total populasi yaitu sebesar 86 orang. Pengambilan sampel menggunakan probability sampling dengan teknik cluster random dan proportional random sampling. Pengumpulan data dilakukan dengan kuesioner.

Analisa bivariate untuk menganalisis hasil motivasi terhadap praktek SADARI sebelum dan sesudah dilakukan pendidikan kesehatan, untuk masing-masing kelompok eksperimen 1 dan kelompok eksperimen 2 dibedakan dengan menggunakan uji t test karena data berdistribusi normal. Untuk mengetahuai adanya perbandingan efektivitas pendidikan kesehatan dengan menggunakan metode pemutaran video compact disc dan demonstrasi dilakukan dengan uji Independent $t$ test karena data berdistribusi normal.

\section{HASIL DAN PEMBAHASAN Motivasi responden tentang praktek SADARI.}

Tabel 1. Distribusi Frekuensi Responden Berdasarkan Motivasi Praktek Sadari pada Kelompok Video

\begin{tabular}{lcccc}
\hline \multirow{2}{*}{ Motivasi } & \multicolumn{2}{c}{ Pre test } & \multicolumn{2}{c}{ Post test } \\
\cline { 2 - 5 } & Frekuensi & $\begin{array}{c}\text { Prosen- } \\
\text { tasi }\end{array}$ & Frekuensi & $\begin{array}{c}\text { Prosen- } \\
\text { tasi }\end{array}$ \\
\hline Tinggi & 21 & $48,8 \%$ & 22 & $51,2 \%$ \\
Rendah & 22 & $51,2 \%$ & 21 & $48,8 \%$ \\
Total & 43 & $100 \%$ & 43 & $100 \%$ \\
\hline
\end{tabular}

Tabel 2. Distribusi Frekuensi Responden

Berdasarkan Motivasi Praktek Sadari pada Kelompok Demonstrasi

\begin{tabular}{lcccc}
\hline \multirow{2}{*}{ Motivasi } & \multicolumn{2}{c}{ Pre test } & \multicolumn{2}{c}{ Post test } \\
\cline { 2 - 5 } & Frekuensi & $\begin{array}{c}\text { Prosen- } \\
\text { tasi }\end{array}$ & Frekuensi & $\begin{array}{c}\text { Prosen- } \\
\text { tasi }\end{array}$ \\
\hline Tinggi & 16 & $37,2 \%$ & 20 & $46,5 \%$ \\
Rendah & 27 & $62,8 \%$ & 23 & $53,5 \%$ \\
Total & 43 & $100 \%$ & 43 & $100 \%$ \\
\hline
\end{tabular}

Pada pre test ditemukan hasil sebagian responden dalam kategori rendah $(51,2 \%)$, sedang pada post test ditemukan $(48,88 \%)$ dalam kategori rendah. Masih ditemukan yang mengatakan keinginan dalam melakukan pemeriksaan SADARI tidak untuk meningkatkan status kesehatan sendiri, dorongan dari dalam diri sendiri masih kurang, sarana dan alat yang tersedia terbatas sehingga kurang memotivasi untuk melakukan pemeriksaan payudara, keteraturan dalam melakukan pemeriksaan belum dapat dilakukan, dorongan keluarga yang kurang sehingga responden kurang termotivasi dalam melakukan tindakan, Ada tiga komponen utama dalam motivasi yaitu: Kebutuhan: bila individu 
merasa ada ketidak seimbangan antara apa yang ia miliki dan yang ia harapkan. Dorongan: merupakan kekuatan mental untuk melakukan kegiatan dalam rangka memenuhi harapan dan tujuan yang ingin dicapai oleh seorang individu. Motivasi dapat menjelaskan mengapa ada orang berperilaku tertentu untuk mencapai tujuan yang berkaitan dengan pekerjaannya ( Notoadmojo, 2010; Azwar,2005; uno, 2011).

\section{Perbandingan Efektivitas Metode Demontrasi dan Pemutaran Video SADARI terhadap Peningkatan Motivasi Deteksi Dini Kanker Payudara.}

a. Hasil perbandingan Pre-test Motivasi responden pada kelompok Demontrasi dan Video Praktek SADARI

Analisis dilakukan untuk mengetahui motivasi responden sebelum diberikan penyuluhan kesehatan dengan metode Demontrasi dan pemutaran Video.

Tabel 3. Hasil perbandingan Pre Test Motivasi responden pada kelompok

Demontrasi dan Video Praktek SADARI

\begin{tabular}{llllrrrr}
\hline & Kelompok & N & Mean & Std. Deviation & Std. Error Mean & t & Df \\
\hline \multirow{2}{*}{ Pre_Test } & Demonstrasi & 43 & 47,3953 & 4,60403 &, 70211 &,- 367 & 84 \\
& Video & 43 & 47,7209 & 3,54781 &, 54104 & & \\
\hline
\end{tabular}

Hasil perhitungan $\mathrm{t}$ statistik diperoleh nilai $t_{\text {hitung }}$ sebesar 0,367 , sedangkan $t_{\text {tabel }}$ sebesar 1,67 , karena $t_{\text {hitung }}(0,367)<t_{\text {tabel }}$ $(1,67)$ maka Ha ditolak, artinya tidak ada perbedaan skor motivasi antara kelompok demontrasi dan kelompok VCD sebelum adanya eksperimen. Hal ini menunjukkan kedua kelompok sebelum dilakukan eksperimen motivasinya setara atau sama. b. Hasil Perbandingan Post-test responden pada kelompok Demonstrasi dan video SADARI terhadap peningkatan motivasi deteksi dini kanker payudara.

Analisis dilakukan untuk mengetahui motivasi responden sesudah diberikan penyuluhan kesehatan dengan metode Demontrasi dan pemutaran Video Compact Disc.

Tabel 4. Hasil Perbandingan Post-test Motivasi Responden pada Kelompok Demontrasi dan VCD Praktek SADARI

\begin{tabular}{llrlrrrr}
\hline & Kelompok & N & Mean & Std. Deviation & Std. Error Mean & T & Df \\
\hline \multirow{2}{*}{ Post_Test } & Demonstrasi & 43 & 52,2791 & 4,09602 &, 62464 & 3,400 & 84 \\
& VCD & 43 & 49,8140 & 2,41282 &, 36795 & & \\
\hline
\end{tabular}

Hasil perhitungan $\mathrm{t}$ statistik diperoleh nilai $t_{\text {hitung }}$ sebesar 3,400, sedangkan $t_{\text {tabel }}$ sebesar 1,67 , karena $t_{\text {hitung }}(3,400)>t_{\text {tabel }}(1,67)$ maka Ha ditolak, artinya ada perbedaan signifikan skor motivasi antara kelompok demontrasi dan kelompok VCD setelah dilakukan eksperimen. Hasil penelitian menunjukkan pada kelompok demontrasi setelah eksperimen dengan rata-rata skor motivasi lebih tinggi, yaitu sebesar 52,28 sedangkan pada kelompok VCD sebesar 49,81. Artinya metode demontrasi lebih efektif digunakan dalam meningkatkan motivasi praktek SADARI dibandingkan dengan metode pemu- taran video SADARI. Penggunaan metode demonstrasi mempunyai suatu dampak yang lebih pada penyuluhan kesehatan yaitu menarik pada orang-orang (sasaran) sehingga dapat meningkatkan pengetahuan, mempengaruhi pendapat umum, memperkenalkan jalan hidup baru dalam bidang kesehatan serta mencakup wilayah perkotaan dan masyarakat pedesaan.

Hal ini sesuai dengan penelitian Suparmi (2014) bahwa metode demontrasi bisa meningkatkan motivasi dalam praktik SADARI. Metode demonstrasi adalah penyajian dengan menunjukkan urutan prosedur pembuatan sesuatu atau proses terjadinya sesuatu untuk mencapai tujuan 
pengajaran. Beberapa keuntungan dari penggunaan metode demonstrasi yaitu metode ini dapat memberikan suatu ketrampilan tertentu kepada kelompok sasaran, lebih menarik dan lebih mudah dalam memahami sesuatu, perhatian siswa lebih terpusat kan pada pelajaran yang sedang diberikan, kesalahan-kesalahan yang terjadi bila pelajaran itu diceramahkan dapan diatasi melalui pengamatan dan contoh yang nyata.

Dalam penelitian ini menunjukkan hasil setelah dilakukan Demonstrasi tentang SADARI motivasi menjadi meningkat. Pada responden yang diberikan perlakuan dengan metode pemutaran video juga mengalami peningkatan motivasi dibandingkan dengan sebelum diberikan perlakuan.hail ini sejalan dengan teori Sardiman (2010) Media video merupakan media pendidikan yang mengandung unsur audio dan unsur visual, sehingga memberikan informasi yang jelas terhadap pesan yang disampaikan. Pesan yang disampikan dapat berupa fakta, bersifat informatif edukatif maupun instruksional. Menurut Sardiman (2010) kelemahan video adalah menggunakan listrik, memerlukan peralatan yang mahal dan kompleks, perhatian penonton sulit dikuasai, partisipasi jarang diperhatikan. Kurang mampu menampilkan detail dari obyek yang disajikan secara sempurna. Hal ini sesuai dengan hasil penelitian di mana responden saat di putarkan video SADARI banyak yang tidak memperhatikan video.

Motivasi dapat menjelaskan mengapa seseorang terdorong berperilaku tertentu untuk mencapai tujuan yang berkaitan dengan pekerjaannya. Pada prinsipnya teori dorongan ini tidak berbeda dengan teori keseimbangan, hanya penekanannya berbeda. Teori dorongan memberikan tekanan pada hal-hal yang mendorong terjadinya tingkah laku. Motivasi dapat digolongkan menjadi dua yaitu motivasi intrinsik dan motivasi ekstrinsik (Sobur, 2010).

Menurut Abraham Maslow seseorang terdorong oleh kebutuhan tertentu pada saat-saat tertentu. Orang berusaha memuaskan kebutuhan yang paling penting terlebih dahulu. Pada saat kebutuhan tersebut terpenuhi, kebutuhan tersebut akan terhenti sebagai motivator dan dia akan memenuhi kebutuhan paling penting selanjutnya (Notoadmojo,2007; Notoadmojo,2010; Uno, 2011).

Motivasi dapat terbentuk oleh adanya dorongan dari luar dan dari dalam individu.
Dorongan dari luar individu bisa diperoleh dari berbagai media seperti Video Compact Disc dan Demonstrasi (Uno, 2011; Sobur, 2010).

\section{SIMPULAN}

Metode demontrasi lebih efektif digunakan dalam meningkatkan motivasi praktek SADARI dibandingkan dengan metode Video SADARI. Hasil penelitian menunjukkan pada kelompok demontrasi setelah eksperiment dengan rata-rata skor motivasi lebih tinggi, yaitu sebesar 52,28 sedangkan pada kelompok VCD sebesar 49,81.

\section{REFERENSI}

Azwar. S. 2008. Sikap Manusia Teori dan Pengukurannya. Yogyakarta : Liberty.

Dinas Kesehatan Provinsi Jawa Tengah. Profil Kesehatan Provinsi Jawa Tengah tahun 2015.

Dinas kesehatan Kabupaten Sukoharjo. Profil Kesehatan Kabupaten Sukoharjo tahun 2014

Notoatmodjo, S. 2010. Ilmu Perilaku Kesehata. Jakarta: Rhineka Cipta

Notoatmodjo, S. 2010. Metodologi Penelitian Kesehatan. Jakarta: Rineka Cipta

Notoatmodjo S. 2007. Kesehatan Masyarakat: Ilmu Dan Seni, Edisi Revisi. Rineka Cipta. Jakarta

Notoatmodjo, S. 2007. Promosi Kesehatan dan Ilmu Perilaku. Jakarta: Rineka Cipta

Notoatmodjo, S., 2010. Pendidikan dan perilaku kesehatan, Jakarta: PT Rineka Cipta

Sardiman, AM. 2010.Pengembangan Kurikulum Teori dan Praktek. Cetakan kedua belas.Banadung :Tarsito

Sobur, A. 2010. Psikologi Umum.Bandung: Pustaka Setiya.

Suparmi, Winarni.2014. Peningkatan Motivasi Deteksi Dini Kanker Payudara dengan Pendidikan Kesehatan metode Demonstrasi. Proceeding Simposium Nasional 2016. Fakultas Kedokteran UNS.

Uno HB.2011. Teori Motivasi dan Pengukurannya. Jakarta: Bumi Aksara 